\title{
An epidemiological study of Serratia marcescens isolates from nosocomial infections by enzyme electrophoresis
}

\author{
P. GOULLET† and B. PICARD*
}

Laboratoire de Microbiologie, Faculté de Médecine Xavier Bichat, Université Paris VII, 16 rue Henri Huchard, 75018 Paris and * Laboratoire de Microbiologie, Faculté de Médecine de Brest, 22 Avenue Camille Desmoulins, 29200 Brest, France

\begin{abstract}
Serratia marcescens isolates from 164 patients with suspected nosocomial infection in several hospitals in the greater Paris region were investigated by analysis of the electrophoretically demonstrable allelic variations of gene loci coding for five esterases and five other enzymes. All the loci were polymorphic and the mean number of alleles per locus was 6.1. A total of 72 distinctive electrophoretic types (ETs) representing multilocus genotypes was distinguished. The isolates were divided into two groups according to their resistance to antibiotics: 82 multiresistant isolates (MRI) and 82 relatively susceptible isolates (RSI). Seventy-two MRI $(\mathbf{8 8 \%})$ were in four genetically related ETs: ET1, ET2, ET8 and ET9; ET1 was found in 48 isolates, whereas the remaining MRI were in 10 ETs, and all RSI in 61 ETs. Three ETs contained both MRI and RSI. The mean coefficients of genetic diversity for the 10 enzyme loci among ETs and isolates were smaller for MRI than for RSI, while the modal ET of MRI resembled that of RSI. The epidemiological significance of isolates varied according to their ET. Thus, isolates belonging to ET1, ET2 and ET8 were responsible for outbreaks or for sporadic infections, whereas isolates of other ETs were responsible for only sporadic infections. The temporal distribution of ET1 isolates among hospitals identified seven outbreaks in seven clinical departments.
\end{abstract}

\section{Introduction}

Serratia marcescens is an important cause of nosocomial infections in the USA and several other parts of the world [1-6]. This opportunist pathogen is frequently responsible for sporadic or epidemic infections, with the possibility of intra-hospital and inter-hospital spread [7]. The morbidity and mortality of these infections are generally due to the serious underlying diseases of patients and the multiple antibiotic resistance of infecting strains. Some of the strains causing nosocomial infections have been found to produce plasmid-mediated $\beta$-lactamases active against extended-spectrum cephalosporins [8-11].

The use of epidemiological markers is essential in order to determine the origin of infections and to help prevent patient-to-patient dissemination. Many methods can be used to identify the epidemiological type of isolates. Phenotypic methods, including serotyping,

Received 20 Jan. 1997; accepted 24 April 1997.

Corresponding author: Professor B. Picard.

tDeceased. phage typing, bacteriocin typing, biotyping and antimicrobial susceptibility testing, have been used to study nosocomial outbreaks [12-14]. However, molecular methods that investigate the polymorphism of DNA or proteins by electrophoresis of enzymes [1519] or whole-cell and periplasmic proteins [17, 20, 21], by DNA restriction endonuclease analysis [22], or by plasmid profiles [23-26], ribotyping [27, 28] and PCR fingerprinting [29], can all be more discriminating than conventional methods. They also provide a better understanding of epidemiology by their capacity to evaluate the genetic relationships between isolates on the basis of comparisons of electrophoretic band patterns. Plasmid profiles have recently been used to classify multiresistant isolates by replicon typing [30], but this technique is limited to the study of isolates with extra-chromosomal DNA, whereas ribotyping and PCR fingerprinting can usually be used for all isolates. The advantage of enzyme electrophoresis is the great specificity of the electrophoretic bands, as the mobility variants of each enzyme can be directly equated to alleles of a single locus. Earlier studies found that the great polymorphism of esterases makes them reliable molecular markers for differentiating between indivi- 
dual bacterial strains and for investigating $S$. marcescens nosocomial infections $[15,18,19,31]$.

This report describes the electrophoretic polymorphism of five esterases and five other enzymes in isolates taken from 164 patients in several hospitals in the greater Paris region. The polymorphism was used to evaluate the genetic relationships between multiresistant isolates and to describe epidemic outbreaks and sporadic infections.

\section{Materials and methods}

\section{Bacterial isolates}

A total of 164 isolates suspected of causing nosocomial infections was taken from 164 patients in various surgical and medical departments, including intensive care units, of four university hospitals in the greater Paris region. The isolates were obtained between July 1992 and March 1994 for hospitals A, B and C, and from November 1992 to January 1993 for hospital D. The 164 clinical isolates were assigned to one of four categories according to their origin: (i) 26 (16\%) were from blood (20) or intra-vascular catheters (6); (ii) 51 (31\%) were from the urinary tract; (iii) 41 (25\%) were from the respiratory tract (bronchial aspiration, bronchial fibroscopy, broncho-alveolar lavage); and (iv) 46 (28\%) were of other origins (pus, 9; drains, 8; swabs, 5; skin or skin wounds, 5; miscellaneous, 19) (Table 1). A second group of 104 isolates was collected under the same conditions between April 1994 and March 1995 from hospitals A, B and C. These were examined for a subsequent epidemiological study.

Isolates were identified as $S$. marcescens by the API $20 \mathrm{E}$ system (bioMérieux, Marcy l'Etoile, France).

\section{Antimicrobial susceptibility}

Susceptibility to antimicrobial agents was tested by the disk diffusion method on Mueller-Hinton Agar (Sanofi Diagnostics Pasteur SA, Marnes-la-Coquette, France) in accordance with the recommendations of the Comite de l'Antibiogramme de la Société Française de Microbiologie [32]. The following antibiotics were tested: amoxicillin, piperacillin, ticarcillin, cephalothin, cefoxitin, cefuroxime, cefotaxime, imipenem, gentamicin, tobramycin, netilmicin, amikacin, chloramphenicol, tetracycline, nalidixic acid and trimethoprim-sulphamethoxazole. In the context of the present study, the term resistant includes resistant isolates and also isolates showing intermediate resistance. Extendedspectrum $\beta$-lactamase was detected by the double-disk synergy test $[9,33]$.

\section{Preparation of bacterial extracts}

Bacteria were grown for $18 \mathrm{~h}$ at $37^{\circ} \mathrm{C}$ with constant agitation in L broth [34] without glucose and collected by centrifugation. The pellets were washed with $60 \mathrm{mM}$ Tris-glycine buffer, $\mathrm{pH} 8.7$, and resuspended in the same buffer. The cells were disrupted by intermittent sonication for $4 \mathrm{~min}$ at $4^{\circ} \mathrm{C}$ and the sonicates were stored at $-20^{\circ} \mathrm{C}$ until used.

\section{Electrophoresis}

Horizontal slab gel electrophoresis was performed in a composite polyacrylamide-agarose gel with acrylamide $7 \% \mathrm{w} / \mathrm{v}$ and a discontinuous Tris-glycine buffer, $\mathrm{pH}$ 8.7 , at constant voltage $(7 \mathrm{~V} / \mathrm{cm})$ until the bromophenol blue marker had run $13 \mathrm{~cm}[35,36]$. The mobility of each enzyme in each isolate was determined at least twice and isolates showing the same mobility for one enzyme were run side-by-side in the same gel for verification. The mobility variants of each enzyme were numbered in order of decreasing migration towards the anode (for nine enzymes) or towards the cathode (for one enzyme) and were interpreted as products of different alleles at the corresponding structural gene locus. Distinctive combinations of alleles over the 10 loci assayed (multilocus genotypes) were designated as electrophoretic types (ETs).

\section{Specific enzyme staining}

The 10 enzymes studied: mannitol 1-phosphate dehydrogenase (M1P), 3-hydroxybutyrate dehydrogenase

Table 1. Origins of the 164 S. marcescens isolates*

\begin{tabular}{|c|c|c|c|c|c|c|c|c|c|c|}
\hline \multirow[b]{3}{*}{ Specimen origin } & \multicolumn{10}{|c|}{ Number of isolates from hospital } \\
\hline & \multicolumn{2}{|c|}{ A } & \multicolumn{2}{|c|}{ B } & \multicolumn{2}{|c|}{$\mathrm{C}$} & \multicolumn{2}{|c|}{$\mathrm{D}$} & \multicolumn{2}{|c|}{ Total } \\
\hline & $\begin{array}{c}\text { Total } \\
\text { isolates }\end{array}$ & $\begin{array}{c}\text { ET1 } \\
\text { isolates }\end{array}$ & $\begin{array}{c}\text { Total } \\
\text { isolates }\end{array}$ & $\begin{array}{c}\text { ET1 } \\
\text { isolates }\end{array}$ & $\begin{array}{c}\text { Total } \\
\text { isolates }\end{array}$ & $\begin{array}{c}\text { ET1 } \\
\text { isolates }\end{array}$ & $\begin{array}{c}\text { Total } \\
\text { isolates }\end{array}$ & $\begin{array}{c}\text { ET1 } \\
\text { isolates }\end{array}$ & $\begin{array}{c}\text { Total } \\
\text { isolates }\end{array}$ & $\begin{array}{c}\text { ET1 } \\
\text { isolates }\end{array}$ \\
\hline Blood and intra-vascular catheter & 18 & 4 & 5 & 2 & 2 & 1 & 1 & 0 & 26 & 7 \\
\hline Urinary tract & 16 & 4 & 12 & 4 & 19 & 1 & 4 & 3 & 51 & 12 \\
\hline Respiratory tract & 22 & 10 & 7 & 2 & 10 & 7 & 2 & 0 & 41 & $19^{\ddagger}$ \\
\hline Diverse & 21 & 5 & 16 & 2 & 7 & 3 & 2 & 0 & 46 & 10 \\
\hline Total & 77 & 23 & 40 & 10 & 38 & 12 & 9 & 3 & 164 & 48 \\
\hline
\end{tabular}

*Isolates were mainly from seven departments of surgery, two of neurosurgery, three of nephrology, one of urology, two of respiratory medicine, and rarely from departments of medicine, paediatrics, obstetrics, otorhinolaryngology and ophthalmology. ${ }^{\dagger}$ See Results.

${ }^{\ddagger} \mathrm{ET} 1$ isolates were significantly more frequent in the respiratory tract than in other sites $\left(\chi^{2}=3.92, \mathrm{p}<0.05\right)$. 
(HBD), isocitrate dehydrogenase (IDH), glucose 6phosphate dehydrogenase (G6P), acid phosphatase (ACP) and esterases (EST) were revealed within the gel by specific staining. ACP and esterases were stained as described by Uriel [37]; the other enzymes were stained as described by Selander et al. [38]. The five esterases were classified according to the spectrum of their hydrolytic activity for the following synthetic substrates; $\alpha$ - and $\beta$-naphthyl acetates ( $\alpha$ NA and $\beta$ NA), $\alpha$ - and $\beta$-naphthyl propionates ( $\alpha \mathrm{NP}$ and $\beta \mathrm{NP}$ ), $\alpha$ - and $\beta$-naphthyl butyrates ( $\alpha \mathrm{NB}$ and $\beta \mathrm{NB}$ ) and indoxyl acetate.

\section{Genetic diversity}

The coefficient of genetic diversity (GDC) of a locus was calculated as $h=1-\sum x_{i}^{2}[\mathrm{n} /(\mathrm{n}-1)]$, where $x_{i}$ is the frequency of the $i$ th allele at the locus, $n$ is the number of isolates (164) or ETs (72) in the sample, and $n /(\mathrm{n}-1)$ is a correction for bias in small samples [38]. Mean GDC is the arithmetic average of $h$ over all loci assayed. The GDC among isolates reflects the genetic diversity of enzymes in the population of $S$. marcescens strains studied, whereas the GDC among ETs measures the genetic diversity of enzymes in $S$. marcescens clones (each corresponding to a distinct ET) without epidemiological bias.

\section{Statistical analysis}

The data were summarised in two 2-way tables. The first table had 72 rows, one for each ET, and 33 columns corresponding to the number of allelic variants detected in all ETs for M1P, HBD, IDH, G6P and ACP, plus a column for the absence of each enzyme. The second table had 72 rows and 28 columns, and contained the data for the five esterases. For each column, each strain was coded as binary code: present $=1$ or absent $=0$. Dissimilarity matrices were constructed from the two tables for hierarchical clustering, and two dendrograms were obtained with a model MP100 Olivetti Computer and STAT-ITCF Software (Institut Technique des Céréales et des Fourrages, Paris, France).

\section{Results}

\section{Detection of enzyme bands}

IDH gave a single band of activity, whereas M1P and HBD each gave one major anodal band and a slower migrating minor band; only the major band was considered in the electrophoretic analysis of isolates. The mobility of the faster migrating band of G6P was measured. ACP gave three main bands of hydrolytic activity, designated $\mathrm{A}, \mathrm{B}$ and $\mathrm{C}$ in decreasing order of mobility. Seven variants were defined according to the mobility of the three bands: variant 1 was defined by the most frequent mobility for each band; variants 2 and 3 were defined, respectively, by a faster (2) or a slower (3) band $A$; variants 4 and 5 were defined, respectively, by a faster (4) or a slower (5) band B; variants 6 and 7 were defined by a faster (6) or slower (7) band C. Five types of esterases were biochemically defined [31]. Four of these migrated towards the anode: $\alpha$-esterase ( $\alpha$-EST) hydrolysing $\alpha$ NA and $\alpha$ NP markedly and $\alpha \mathrm{NB}$ weakly; $\beta$-esterase ( $\beta$-EST) hydrolysing $\beta$-naphthyl esters; $\alpha \beta$-esterase ( $\alpha \beta$-EST) hydrolysing $\alpha$ and $\beta$ naphthyl esters; indoxyl acetate esterase (indoxEST) hydrolysing indoxyl acetate rapidly and $\beta \mathrm{NA}$ slowly. One esterase migrated towards the cathode: (C $\alpha$-EST), hydrolysing $\alpha$ NA markedly and $\alpha \mathrm{NP}$ and $\beta \mathrm{NA}$ weakly. When two major bands were characterised as $\alpha$-EST in an isolate, only the faster migrating band was used for analysis. Screening isolates by staining of esterase with $\alpha \mathrm{NA}$ and $\beta \mathrm{NA}$ was useful. Some minor esterase bands which were revealed by these two substrates were not used to compare allelic variations between isolates, but could be useful for additional discrimination between isolates.

\section{Electrophoretic types}

All the 10 enzyme loci were polymorphic, with the number of alleles per locus (including null allele) varying from three ( $\beta$-EST) to nine (HBD) (Table 2 ). No isolate had null alleles at more than two loci. The average number of alleles per locus was 6.1.

The allele profiles of the 164 isolates were compared

Table 2. Allele frequency and genetic diversity at 10 polymorphic loci among ETs and isolates of $S$. marcescens

\begin{tabular}{|c|c|c|c|c|c|c|c|c|c|c|c|c|}
\hline \multirow[b]{2}{*}{ Enzyme locus } & \multirow[b]{2}{*}{$\begin{array}{l}\text { Number of } \\
\text { alleles }\end{array}$} & \multicolumn{9}{|c|}{ Frequency of alleles in different enzymes } & \multicolumn{2}{|c|}{ Genetic diversity of } \\
\hline & & 1 & 2 & 3 & 4 & 5 & 6 & 7 & 8 & 0 & $\begin{array}{c}\text { ETs } \\
(n=72)\end{array}$ & $\begin{array}{l}\text { Isolates } \\
(n=164)\end{array}$ \\
\hline M1P & 6 & 0.013 & 0.305 & 0.444 & 0.111 & 0.111 & 0.013 & & & & 0.693 & 0.561 \\
\hline HBD & 9 & 0.097 & 0.055 & 0.347 & 0.236 & 0.138 & 0.083 & 0.013 & 0.013 & 0.013 & 0.795 & 0.532 \\
\hline IDH & 4 & 0.013 & 0.486 & 0.486 & 0.013 & & & & & & 0.534 & 0.401 \\
\hline G6P & 7 & 0.013 & 0.069 & 0.055 & 0.236 & 0.513 & 0.083 & 0.027 & & & 0.673 & 0.603 \\
\hline $\mathrm{ACP}$ & 7 & 0.333 & 0.013 & 0.250 & 0.097 & 0.027 & 0.055 & 0.222 & & & 0.774 & 0.566 \\
\hline$\alpha$-EST & 8 & 0.125 & 0.097 & 0.041 & 0.166 & 0.097 & 0.333 & 0.111 & 0.027 & & 0.823 & 0.550 \\
\hline$\alpha \beta$-EST & 8 & 0.027 & 0.041 & 0.250 & 0.416 & 0.125 & 0.083 & 0.013 & & 0.041 & 0.747 & 0.781 \\
\hline Indox-EST & 5 & 0.263 & 0.055 & 0.625 & 0.027 & & & & & 0.027 & 0.542 & 0.333 \\
\hline$\beta$-EST & 3 & 0.041 & 0.638 & 0.319 & & & & & & & 0.495 & 0.512 \\
\hline C $\alpha$-EST & 4 & 0.055 & 0.083 & 0.055 & & & & & & 0.805 & 0.387 & 0.601 \\
\hline Mean values & 6.1 & & & & & & & & & & 0.646 & 0.544 \\
\hline
\end{tabular}


to identify 72 distinct ETs (genotypes) among which the mean GDC was 0.646. Of the 72 ETs, 54 were each represented by a single isolate, and 18 were represented by multiple $(2-48)$ isolates. The most common ET ( $29 \%$ of isolates) was designated ET1, and the 71 other ETs were classified according to the number of allelic variants distinct from those of ET1 (Table 3). Thus, the ETs were divided into two groups depending on their genetic relationships with ET1: group I (ET1-ET35) contained ETs differing from ET1 by 3-6 allelic variants; group II (ET36-ET72) contained ETs differing from ET1 by $7-10$ allelic variants. As a consequence of the multiple recovery of ETs, the mean GDC among isolates (0.544) was smaller than among ETs (Table 2). The distribution of the 48 ET1 isolates according to their origin is indicated in Table 1. The proportion of ET1 isolates in specimens from the respiratory tract $(46.3 \%)$ was significantly higher than for specimens of other origins $(23.5 \%), \chi^{2}=3.92, \mathrm{p}<0.05$, whereas 16 of the 19 ET2 isolates were from urine. Twelve isolates belonging to the four most frequent ETs (six isolates of ET1, three of ET2, two of ET8 and one of ET9) were randomly chosen for serotyping (Unité des Entérobactéries, Institut Pasteur, Paris). Nine isolates were identified as belonging to serotype O6,14:H12.

\section{Genotypes according to antibiotic resistance}

The 164 isolates were all resistant to amoxicillin, cephalothin and cefuroxime and susceptible to imipenem, but their susceptibility to the other antibiotics varied. Isolates resistant to at least three of the commonly used antibiotics (piperacillin, ticarcillin, cefoxitin, cefotaxime, gentamicin and tobramycin) were designated mutiresistant isolates (MRI), and the others were designated as relatively susceptible isolates (RSI). The numbers of MRI and RSI were the same. The 82 MRI corresponded to $14 \mathrm{ETs}$, and 79 isolates were classified in group I and only three isolates in group II (ET43, ET44 and ET56). In contrast, the 82 RSI were genetically more heterogeneous, with 61 ETs. RSI were more distantly related to ET1, with 41 isolates belonging to group II.

Three genotypes (ET2, ET8 and ET20) included both MRI and RSI. Most of the MRI (88\%) were in four genetically related ETs (ET1, ET2, ET8 and ET9). All the isolates of ET1 and ET9, and the MRI of ET2 and ET8 were resistant to ticarcillin, piperacillin, tetracycline and nalidixic acid, but their susceptibility to gentamicin, tobramycin, netilmicin, amikacin, chloramphenicol and trimethoprim-sulphamethoxazole var-

Table 3. Allele profile of $72 \mathrm{ETs}$ detected in $164 \mathrm{~S}$. marcescens isolates from hospitalised patients

\begin{tabular}{|c|c|c|c|c|c|c|c|c|c|c|c|c|c|}
\hline \multirow[b]{2}{*}{ ET } & \multicolumn{2}{|c|}{$\begin{array}{l}\text { Number of } \\
\text { isolates }\end{array}$} & \multicolumn{10}{|c|}{ Allele at indicated enzyme locus } & \multirow{2}{*}{$\begin{array}{l}\text { Number of } \\
\text { alleles different } \\
\text { from ET1 }\end{array}$} \\
\hline & MRI & RSI & M1P & HBD & IDH & G6P & $\mathrm{ACP}$ & $\alpha$-EST & $\alpha \beta$-EST & Indox-EST & $\beta$-EST & $\mathrm{C} \alpha-\mathrm{EST}$ & \\
\hline \multicolumn{14}{|c|}{ Group 1} \\
\hline 1 & 48 & 0 & 3 & 3 & 2 & 5 & 1 & 6 & 7 & 3 & 3 & 2 & 0 \\
\hline 2 & 14 & 5 & 2 & 3 & 2 & 6 & 1 & 6 & 0 & 3 & 3 & 2 & 3 \\
\hline 3 & 1 & 0 & 3 & 4 & 2 & 5 & 1 & 6 & 4 & 4 & 3 & 2 & 3 \\
\hline 4 & 0 & 1 & 3 & 5 & 2 & 5 & 1 & 6 & 4 & 3 & 3 & 0 & 3 \\
\hline 5 & 0 & 2 & 3 & 3 & 2 & 5 & 6 & 6 & 3 & 3 & 3 & 0 & 3 \\
\hline 6 & 0 & 2 & 3 & 3 & 2 & 5 & 1 & 6 & 5 & 3 & 2 & 0 & 3 \\
\hline 7 & 0 & 3 & 3 & 3 & 2 & 5 & 1 & 6 & 4 & 3 & 2 & 0 & 3 \\
\hline 8 & 5 & 2 & 3 & 3 & 2 & 6 & 1 & 6 & 4 & 3 & 2 & 1 & 4 \\
\hline 9 & 5 & 0 & 3 & 3 & 2 & 5 & 7 & 6 & 4 & 3 & 2 & 3 & 4 \\
\hline 10 & 0 & 1 & 3 & 4 & 2 & 2 & 1 & 6 & 6 & 3 & 3 & 0 & 4 \\
\hline 11 & 0 & 2 & 3 & 3 & 2 & 4 & 1 & 6 & 4 & 3 & 2 & 0 & 4 \\
\hline 12 & 0 & 1 & 3 & 5 & 2 & 2 & 1 & 6 & 6 & 3 & 3 & 1 & 4 \\
\hline 13 & 0 & 1 & 3 & 3 & 2 & 5 & 1 & 2 & 4 & 3 & 2 & 0 & 4 \\
\hline 14 & 0 & 1 & 2 & 3 & 2 & 5 & 1 & 5 & 5 & 3 & 3 & 0 & 4 \\
\hline 15 & 0 & 1 & 3 & 3 & 2 & 5 & 1 & 2 & 3 & 3 & 2 & 0 & 4 \\
\hline 16 & 1 & 0 & 2 & 4 & 2 & 5 & 3 & 6 & 6 & 3 & 3 & 0 & 5 \\
\hline 17 & 1 & 0 & 3 & 3 & 2 & 6 & 7 & 6 & 4 & 3 & 2 & 3 & 5 \\
\hline 18 & 1 & 0 & 3 & 3 & 3 & 5 & 7 & 6 & 4 & 3 & 2 & 3 & 5 \\
\hline 19 & 1 & 0 & 3 & 2 & 3 & 5 & 7 & 6 & 4 & 3 & 2 & 2 & 5 \\
\hline 20 & 1 & 1 & 3 & 3 & 2 & 4 & 1 & 5 & 4 & 3 & 2 & 0 & 5 \\
\hline 21 & 1 & 0 & 2 & 3 & 2 & 5 & 3 & 7 & 4 & 3 & 3 & 3 & 5 \\
\hline 22 & 0 & 2 & 3 & 3 & 2 & 5 & 7 & 7 & 4 & 3 & 2 & 0 & 5 \\
\hline 23 & 0 & 2 & 3 & 5 & 2 & 3 & 1 & 8 & 4 & 3 & 3 & 0 & 5 \\
\hline 24 & 0 & 1 & 3 & 4 & 2 & 5 & 7 & 6 & 3 & 1 & 3 & 0 & 5 \\
\hline 25 & 0 & 1 & 3 & 3 & 2 & 4 & 1 & 5 & 4 & 3 & 2 & 1 & 5 \\
\hline 26 & 0 & 1 & 2 & 3 & 2 & 5 & 7 & 3 & 4 & 3 & 3 & 0 & 5 \\
\hline 27 & 0 & 1 & 2 & 3 & 2 & 5 & 7 & 2 & 4 & 3 & 3 & 0 & 5 \\
\hline 28 & 0 & 2 & 2 & 4 & 3 & 4 & 1 & 6 & 4 & 3 & 3 & 0 & 6 \\
\hline 29 & 0 & 2 & 2 & 4 & 2 & 4 & 1 & 6 & 4 & 3 & 2 & 0 & 6 \\
\hline 30 & 0 & 1 & 6 & 2 & 2 & 6 & 1 & 6 & 4 & 3 & 2 & 0 & 6 \\
\hline 31 & 0 & 1 & 2 & 3 & 2 & 6 & 3 & 7 & 4 & 3 & 3 & 0 & 6 \\
\hline 32 & 0 & 1 & 2 & 5 & 3 & 5 & 3 & 6 & 6 & 3 & 3 & 0 & 6 \\
\hline 33 & 0 & 1 & 2 & 3 & 2 & 5 & 7 & 5 & 3 & 3 & 2 & 0 & 6 \\
\hline 34 & 0 & 1 & 3 & 4 & 2 & 4 & 3 & 7 & 3 & 3 & 3 & 0 & 6 \\
\hline 35 & 0 & 1 & 2 & 3 & 2 & 2 & 1 & 7 & 6 & 3 & 2 & 0 & 6 \\
\hline
\end{tabular}


Table 3. (continued)

\begin{tabular}{|c|c|c|c|c|c|c|c|c|c|c|c|c|c|}
\hline \multirow[b]{2}{*}{ ET } & \multicolumn{2}{|c|}{$\begin{array}{c}\text { Number of } \\
\text { isolates }\end{array}$} & \multicolumn{10}{|c|}{ Allele at indicated enzyme locus } & \multirow{2}{*}{$\begin{array}{l}\text { Number of } \\
\text { alleles different } \\
\text { from ET1 }\end{array}$} \\
\hline & MRI & RSI & M1P & HBD & IDH & G6P & $\mathrm{ACP}$ & $\alpha$-EST & $\alpha \beta$-EST & Indox-EST & $\beta$-EST & $\mathrm{C} \alpha$-EST & \\
\hline \multicolumn{14}{|c|}{ Group II } \\
\hline 36 & 0 & 3 & 2 & 4 & 3 & 4 & 6 & 6 & 4 & 3 & 3 & 0 & 7 \\
\hline 37 & 0 & 1 & 3 & 4 & 2 & 7 & 7 & 8 & 4 & 3 & 2 & 0 & 7 \\
\hline 38 & 0 & 1 & 3 & 4 & 2 & 6 & 7 & 7 & 4 & 3 & 2 & 0 & 7 \\
\hline 39 & 0 & 1 & 3 & 6 & 3 & 5 & 3 & 2 & 4 & 3 & 2 & 0 & 7 \\
\hline 40 & 0 & 1 & 2 & 0 & 1 & 5 & 3 & 4 & 4 & 3 & 3 & 0 & 7 \\
\hline 41 & 0 & 1 & 3 & 5 & 4 & 5 & 3 & 4 & 2 & 2 & 3 & 0 & 7 \\
\hline 42 & 0 & 1 & 3 & 4 & 3 & 2 & 7 & 6 & 3 & 3 & 2 & 0 & 7 \\
\hline 43 & 1 & 0 & 4 & 1 & 3 & 5 & 1 & 1 & 3 & 1 & 2 & 0 & 8 \\
\hline 44 & 1 & 0 & 4 & 1 & 3 & 5 & 7 & 1 & 3 & 1 & 2 & 2 & 8 \\
\hline 45 & 0 & 3 & 4 & 3 & 3 & 5 & 4 & 1 & 3 & 1 & 2 & 0 & 8 \\
\hline 46 & 0 & 2 & 3 & 5 & 3 & 3 & 1 & 2 & 5 & 1 & 1 & 0 & 8 \\
\hline 47 & 0 & 1 & 3 & 5 & 3 & 1 & 1 & 2 & 5 & 1 & 1 & 0 & 8 \\
\hline 48 & 0 & 2 & 2 & 4 & 3 & 5 & 4 & 5 & 3 & 1 & 3 & 0 & 8 \\
\hline 49 & 0 & 1 & 4 & 3 & 3 & 5 & 7 & 5 & 3 & 1 & 2 & 0 & 8 \\
\hline 50 & 0 & 1 & 2 & 4 & 2 & 5 & 6 & 7 & 4 & 1 & 2 & 0 & 8 \\
\hline 51 & 0 & 1 & 5 & 6 & 3 & 5 & 3 & 4 & 0 & 3 & 2 & 0 & 8 \\
\hline 52 & 0 & 1 & 2 & 6 & 3 & 5 & 3 & 3 & 5 & 3 & 2 & 1 & 8 \\
\hline 53 & 0 & 1 & 3 & 1 & 3 & 5 & 7 & 4 & 4 & 0 & 2 & 0 & 8 \\
\hline 54 & 0 & 1 & 3 & 4 & 3 & 3 & 3 & 4 & 5 & 2 & 3 & 0 & 8 \\
\hline 55 & 0 & 1 & 2 & 5 & 3 & 2 & 1 & 4 & 2 & 2 & 2 & 2 & 8 \\
\hline 56 & 1 & 0 & 5 & 6 & 3 & 4 & 3 & 2 & 5 & 3 & 2 & 0 & 9 \\
\hline 57 & 0 & 2 & 2 & 4 & 2 & 4 & 6 & 7 & 4 & 0 & 2 & 0 & 9 \\
\hline 58 & 0 & 1 & 5 & 1 & 3 & 5 & 5 & 1 & 3 & 1 & 2 & 0 & 9 \\
\hline 59 & 0 & 1 & 4 & 3 & 3 & 4 & 3 & 1 & 3 & 1 & 2 & 0 & 9 \\
\hline 60 & 0 & 1 & 4 & 1 & 3 & 5 & 5 & 1 & 3 & 1 & 2 & 0 & 9 \\
\hline 61 & 0 & 1 & 4 & 2 & 3 & 4 & 4 & 1 & 3 & 1 & 2 & 0 & 9 \\
\hline 62 & 0 & 1 & 3 & 2 & 3 & 4 & 4 & 5 & 3 & 1 & 2 & 0 & 9 \\
\hline 63 & 0 & 1 & 2 & 5 & 3 & 4 & 4 & 6 & 2 & 2 & 2 & 0 & 9 \\
\hline 64 & 0 & 1 & 1 & 5 & 3 & 5 & 2 & 4 & 1 & 1 & 1 & 0 & 9 \\
\hline 65 & 0 & 1 & 2 & 4 & 3 & 5 & 4 & 4 & 1 & 1 & 2 & 0 & 9 \\
\hline 66 & 0 & 1 & 5 & 7 & 3 & 4 & 3 & 4 & 5 & 3 & 2 & 0 & 9 \\
\hline 67 & 0 & 1 & 2 & 8 & 3 & 4 & 3 & 4 & 4 & 3 & 2 & 0 & 9 \\
\hline 68 & 0 & 1 & 5 & 6 & 3 & 5 & 3 & 4 & 0 & 4 & 2 & 0 & 9 \\
\hline 69 & 0 & 1 & 5 & 4 & 3 & 7 & 3 & 4 & 6 & 3 & 2 & 0 & 9 \\
\hline 70 & 0 & 1 & 4 & 1 & 3 & 3 & 4 & 1 & 3 & 1 & 2 & 0 & 10 \\
\hline 71 & 0 & 1 & 5 & 1 & 3 & 4 & 7 & 1 & 3 & 1 & 2 & 0 & 10 \\
\hline 72 & 0 & 1 & 5 & 6 & 3 & 4 & 3 & 3 & 5 & 1 & 2 & 0 & 10 \\
\hline
\end{tabular}

MRI, multiresistant isolates; RSI, relatively susceptible isolates.

ied. Thus, 27 ET1 isolates were resistant to gentamicin, eight to tobramycin and netilmicin, 12 to chloramphenicol and 46 to trimethoprim-sulphamethoxazole. Six ET1 isolates, seven ET2 isolates and one ET8 isolate also produced extended-spectrum $\beta$-lactamase.

The modal genotypes for MRI and RSI were constructed by taking the most frequent allele at each of the 10 enzyme loci in the 72 ETs. The modal ET of MRI was similar to that for RSI, with the exception of the C $\alpha$-EST locus (Table 4). Thus, the two populations have some similarities in their genetic framework.

The mean GDCs of ETs and of isolates for the 10 enzyme loci were higher for RSI than for MRI. However, for MRI, the mean GDCs were higher for the five esterases than for five other enzymes, whereas with RSI, the mean GDCs were higher for the five other enzymes than for esterases (Table 5). The genetic differences between MRI and RSI revealed by the mean GDCs for esterases and for other enzymes were subsequently investigated by separate statistical analyses of the two categories of enzymes.

\section{Statistical analysis}

The dissimilarity between the 72 ETs studied by allelic variation of M1P, HBD, IDH, G6P and ACP was used to construct a dendrogram (Fig. 1). Five clusters of ETs

Table 4. Modal ETs of multiresistant (MRI) and relatively sensitive isolates (RSI) of $S$. marcescens*

\begin{tabular}{lcccccccccc}
\hline & \multicolumn{10}{c}{ Allele at indicated enzyme locus } \\
\cline { 2 - 11 } Isolate & M1P & HBD & IDH & G6P & ACP & $\alpha$-EST & $\alpha \beta$-EST & Indox-EST & $\beta$-EST & C $\alpha$-EST \\
\hline MRI & 3 & 3 & 2 & 5 & 1 & 6 & 4 & 3 & 2 \\
RSI & 3 & 3 & $3,2^{\dagger}$ & 5 & 1 & 6 & 4 & 3 & 2 & 0 \\
\hline
\end{tabular}

${ }^{*}$ Modal ETs are combinations of the most frequent allele at each of 10 enzyme loci (Table 3 ).

${ }^{\dagger}$ Allele 3 for 30 ETs and allele 2 for 29 ETs. 
Table 5. Genetic diversity of ETs and isolates among multiresistant (MRI) and relatively sensitive isolates (RSI)

\begin{tabular}{|c|c|c|c|c|c|c|c|c|c|}
\hline \multirow[b]{2}{*}{ Isolate } & \multirow[b]{2}{*}{$\begin{array}{c}\text { Number of } \\
\text { ETs }\end{array}$} & \multirow[b]{2}{*}{$\begin{array}{l}\text { Number of } \\
\text { isolates }\end{array}$} & \multirow[b]{2}{*}{ ETs/isolates } & \multicolumn{3}{|c|}{ Mean genetic diversity of ETs } & \multicolumn{3}{|c|}{ Mean genetic diversity of isolates } \\
\hline & & & & $\begin{array}{l}\text { for five } \\
\text { esterases }\end{array}$ & $\begin{array}{l}\text { for five other } \\
\text { enzymes }\end{array}$ & $\begin{array}{l}\text { for } 10 \\
\text { enzymes }\end{array}$ & $\begin{array}{l}\text { for five } \\
\text { esterases }\end{array}$ & $\begin{array}{l}\text { for five other } \\
\text { enzymes }\end{array}$ & $\begin{array}{c}\text { for } 10 \\
\text { enzymes }\end{array}$ \\
\hline MRI & 14 & 82 & 0.17 & 0.582 & 0.528 & 0.555 & 0.296 & 0.260 & 0.278 \\
\hline RSI & 61 & 82 & 0.74 & 0.570 & 0.707 & 0.639 & 0.565 & 0.686 & 0.626 \\
\hline
\end{tabular}

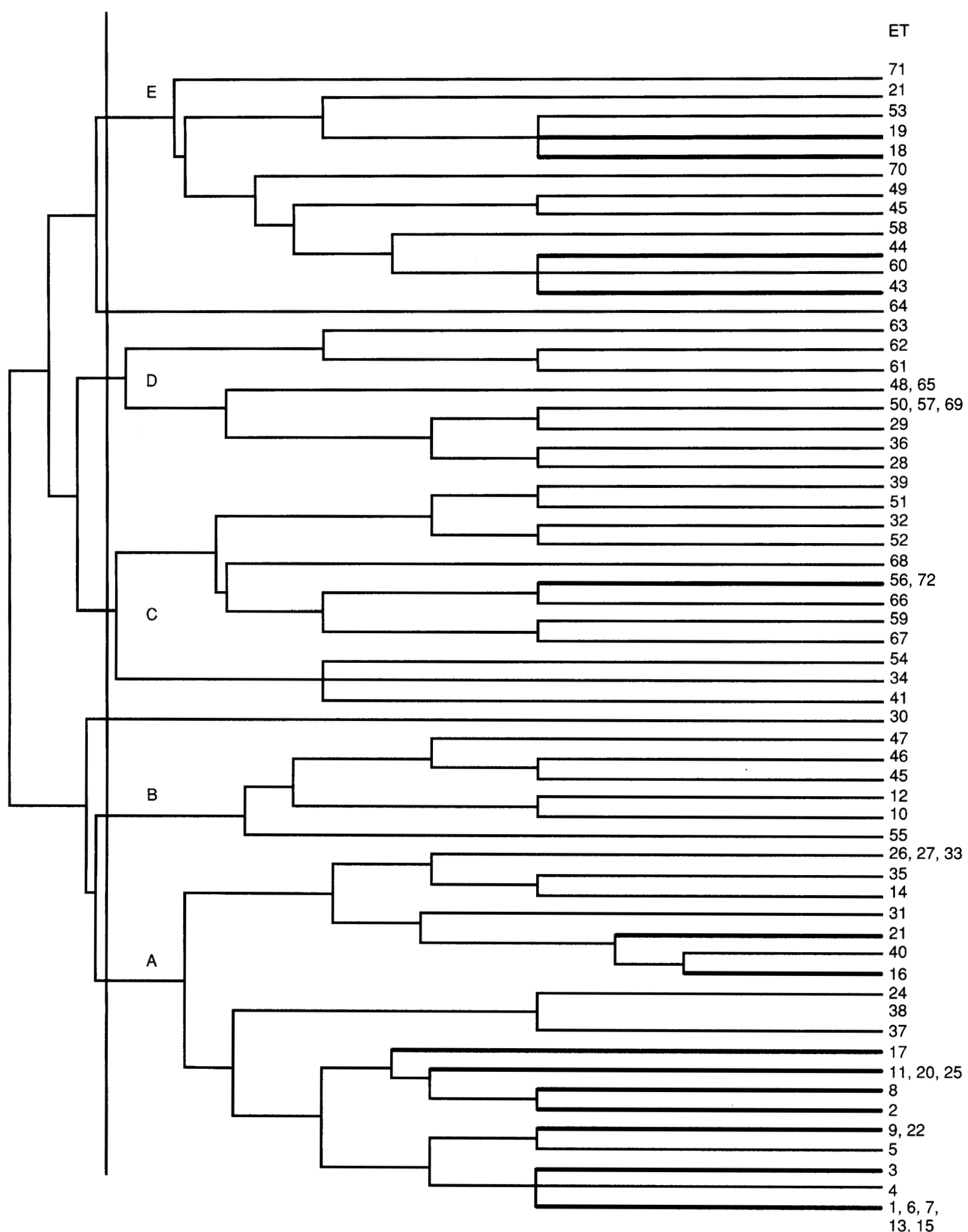

Fig. 1. Dendrogram of ETs prepared from the dissimilarity matrix distance for M1P, HBD, IDH, G6P and ACP. Each branch corresponding to an ET of MRI is indicated in bold. 
(A, B, C, D and E) can be distinguished. For RSI, the ETs were dispersed among the five clusters. For MRI, nine ETs, including ET1, ET2, ET8 and ET9, were found in cluster A; four ETs were in cluster E and only one ET was in cluster C. Thus, clusters B and D contained only ETs corresponding to RSI. In contrast, the dendrogram constructed from the esterase electrophoretic polymorphism data revealed a wide distribution of ETs for both RSI and MRI (data not shown).

\section{Genotypes as epidemiological markers}

The epidemiological significance of isolates in different clinical departments varied according to their genotype. Table 6 shows the distribution of isolates corresponding to the four most frequent ETs found in departments of the three main hospitals investigated between July 1992 and March 1994. The major features were the wide distribution of ET1 isolates (17 departments), and the predominance of ET2 isolates in one department (hospital C). Fig. 2 shows the temporal distribution of
45 ET1 isolates in 17 departments of hospitals A, B and $\mathrm{C}$, and of 13 ET2 isolates in one department of hospital C. The diagram indicates a continuing involvement of ET1 isolates in $S$. marcescens nosocomial infections, and describes epidemic episodes. The infected patients in six departments formed clusters of three-to-six cases over a 2-4-month period, with the possible resurgence of infection after a longer period (over 6 months). All ET1 isolates from departments $\mathrm{A} 1$ and $\mathrm{A} 2$ were sensitive to four aminoglycosides (gentamicin, tobramycin, netilmicin and amikacin), while all isolates from department $A 3$ were resistant to gentamicin. In 10 other departments (A5 and A6, B2 to B7, and C3 and C4), only one or two patients were infected by ET1 isolates. The ET2 isolates were responsible for a prolonged outbreak ( $>1$ year) affecting 13 hospitalised patients in department C3. Seven isolates were resistant to the four aminoglycosides and produced extended-spectrum $\beta$ lactamase. In contrast to isolates of ET1 and ET2, the isolates belonging to other ETs isolated from July 1992 to March 1994 were responsible only for sporadic

Table 6. Distribution of isolates belonging to the four most frequent ETs

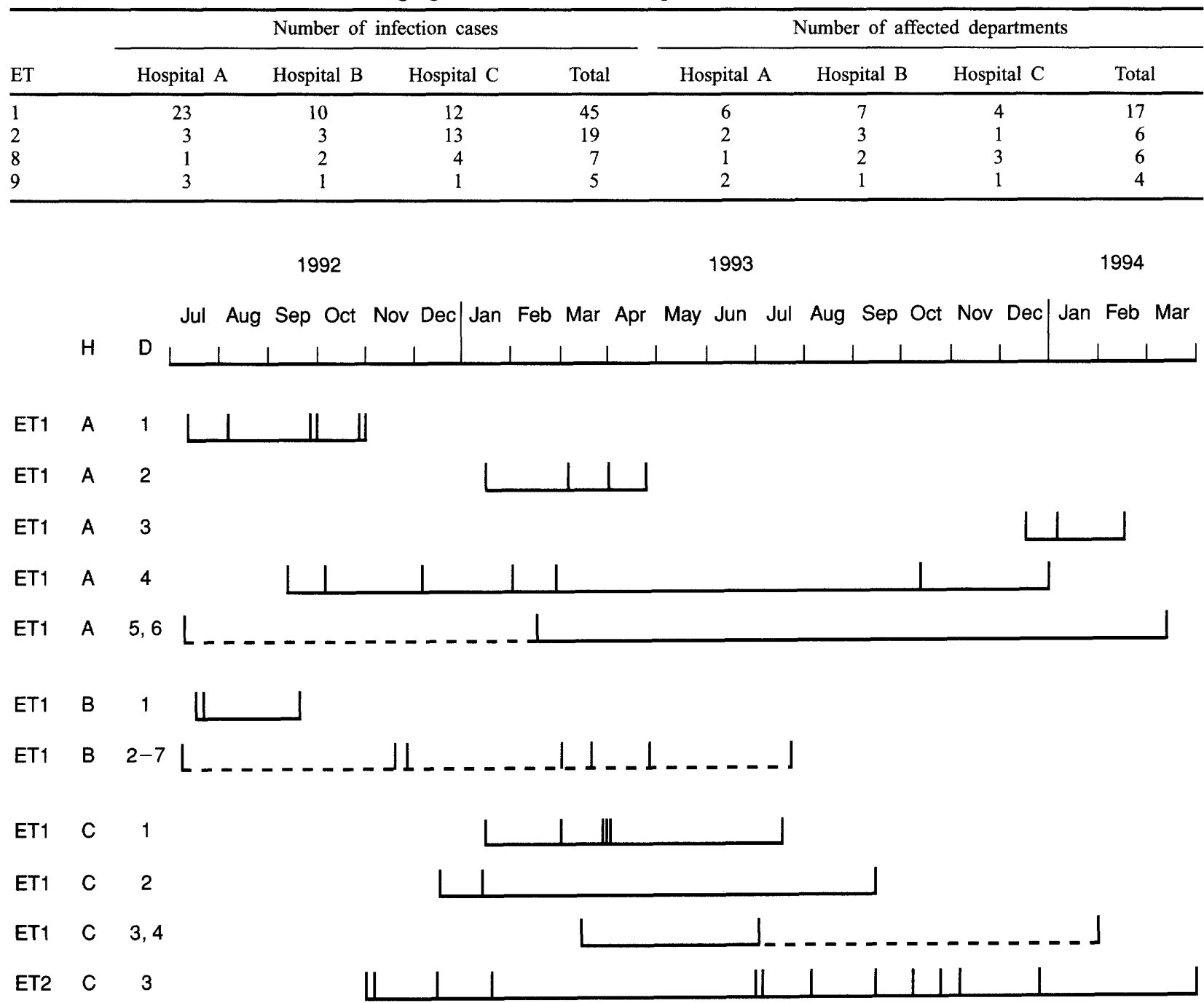

Fig. 2. Temporal distribution of ET1 and ET2 isolates among 17 departments of three hospitals. (H), hospitals designated A, B and C; (D), departments designated 1-7; isolates from the same department are joined by continuous lines, those from different departments are linked by dotted lines. 
infections with no epidemiological relationship, except for isolates of ET9 (MRI) and of ET48 (RSI) which were each obtained from patients hospitalised during the same period in the same department.

The study of 104 isolates obtained between April 1994 and March 1995 revealed 16 new cases of ET1 infection, including one epidemic outbreak. There were 11 new cases of ET8 infection, including an outbreak of five cases in department A1, whereas only one case of ET2 infection was detected.

\section{Discussion}

Enzyme electrophoresis is currently used to study the genetic structure of bacterial populations and provides extensive data for systematics and epidemiology. In a previous study, Gargallo-Viola determined the genetic relationships between $99 \mathrm{~S}$. marcescens isolates obtained from clinical and environmental sources in several countries, by analysing the allelic variations of gene loci coding for nine enzymes other than esterases [39]. Seven of the loci were polymorphic and 33 distinctive ETs representing genotypes were identified. The average number of alleles per locus was three, the GDC of ETs was 0.376 and the GDC of isolates was 0.315 . The structure of the bacterial population was clonal.

This report describes the genotypes of 164 isolates from hospitalised patients, determined by the allelic variations of gene loci coding for five esterases and five other enzymes. All 10 enzyme loci were polymorphic and 72 ETs were identified. Because nine of the 10 enzymes were expressed in $96-100 \%$ of the ETs, we presume that the corresponding structural gene loci are located on the chromosome rather than on plasmids. The average number of alleles per locus (6.1), the GDC (0.646) of ETs and the GDC (0.544) of isolates were higher than those previously observed [39]. This difference may be due to the distinct origins of isolates and also in part to the nature of the enzymes studied, as $\alpha$-EST, $\alpha \beta$-EST, ACP and HBD are all highly polymorphic. The great genetic heterogeneity of the 164 isolates, indicated by multilocus electrophoresis, reinforces considerably the heterogeneity of isolates from hospitalised patients previously indicated by bacteriological methods [40] and ribotyping (41 ribotypes for 209 isolates) [28].

This study compared the genetic structure of a significant number of multiresistant isolates with that of other $S$. marcescens isolates. Although these two isolate populations had some similarities in their genetic framework, the MRI were considerably less diverse in their genotype than were the RSI. The mean GDC of ETs and the mean GDC of isolates were significantly lower for MRI than for RSI. Thus, most MRI ( 72 isolates), could be assigned to one of four genetically related ETs (ET1, ET2, ET8 and ET9), whereas only three isolates (ET44, ET45 and ET56) differed significantly from the four most frequent ETs by eight or nine allelic variants. These findings were corroborated by the dendrogram computed from the electrophoretic polymorphism of M1P, HBD, IDH, G6P and ACP, showing that most MRI were in the same cluster. On the other hand, the wide distribution of ETs for both MRI and RSI in the dendrogram constructed from the esterase electrophoretic polymorphism data was in agreement with the mean GDCs of these enzymes, which were at the same level for the MRI and RSI. This indicates that the allelic variations of esterases were independent of the resistance of isolates to antibiotics. Nevertheless, $\mathrm{C} \alpha$-EST was more frequently detected in MRI $(95 \%$ of isolates), than in RSI $(6 \%)$. The occurrence of several distantly related ETs among MRI correlates well with the expansion of plasmid resistance in $S$. marcescens populations $[11,23,25]$. The diversity of phenotype patterns of antibiotic resistance among isolates belonging to the same ET could be explained by presence or absence of transferable elements carrying resistance genes. The propensity of plasmids to develop multiple resistance to antimicrobial agents, with a potential role as a gene reservoir for resistance to $\beta$-lactam agents and aminoglycosides, indicates the increasing risk of resistant infections in the future, both from the spread of bacterial agents themselves, and by dissemination of drug resistance by inter- or intra-species plasmid exchanges [25]. In this respect, enzyme electrophoresis is useful for evaluating the spread of a multiresistant strain, whereas plasmid profile determination is suitable for assessing the spread of a plasmid transferring drug resistance.

Epidemiological surveys of isolates based on enzyme genotyping provide a good way of describing outbreaks caused by specific isolates. Thus ET1 isolates, which were obtained throughout the investigation (July 1992-March 1995) were responsible for seven epidemic outbreaks. During the same period, ET2 and ET8 isolates were each responsible for only one outbreak, while ET9 and ET22 isolates caused minor episodes. This survey unambiguously demonstrates the existence of independent cross-infections by genetically distinct isolates (ET1 and E'T2) among patients hospitalised in the same department (C3) at the same time (Fig. 2). The isolates belonging to ET1, ET2 and ET8 which caused epidemic outbreaks can be distinguished from each other and from the 69 remaining ETs by allelic variations in their esterases. The staining of electrophoretic bands with $\alpha \mathrm{NA}$ and $\beta \mathrm{NA}$ could be used to screen isolates routinely for large scale epidemiological studies.

Extensive epidemiological investigation of each infected patient was required to determine how the nosocomial strains were introduced and disseminated. Nevertheless, the scattering of isolates belonging to 
the four most frequent ETs suggests that each of them could correspond to an endemic strain harboured by some individuals in the population. When one of these strains is harboured by a hospitalised patient, it can be selected by antibiotic therapy and disseminated throughout a department if infection control measures are deficient. The occurrence of only one or two cases of nosocomial infection in some departments does not exclude the possibility of cross-infection outbreaks caused by inter-departmental dissemination of isolates within a hospital by inanimate vectors, by the staff, or by patients themselves when they are moved around the hospital for medical investigations or therapy. The prevalence of the four genetically related ETs agrees with the prevalence of the 06,14 antigen $[12,14]$ and especially the $\mathrm{O} 6,14: \mathrm{H} 12$ serotype $[3,12,41,42]$ in clinical infections. These ETs could be associated with pathogenicity factors $[14,41,43-45]$ enhancing the infecting capacities of isolates. The spread of ET1 isolates could have occurred because their antibiotic resistance appeared before that of isolates belonging to other ETs, and resistant isolates would then be selected by therapy.

In conclusion, genotyping of $S$. marcescens by enzyme electrophoresis provides an accurate method of characterising clinical isolates. This allows the emergence and subsequent spread of multiresistant strains to be investigated, with confirmation or exclusion of possible epidemiological links between hospital infections.

We are grateful to L. Jacques and P. Vergez for gifts of isolates. We thank Colette Gaillard and Nicole Hautier for technical assistance.

\section{References}

1. Brooks HJL, Chambers TJ, Tabaqchali S. The increasing isolation of Serratia species from clinical specimens. $J \mathrm{Hyg}$ 1979; 82: 31-40.

2. Yu VL. Serratia marcescens. Historical perspective and clinical review. $N$ Engl J Med 1979; 300: 887-893.

3. Minck R, Lavillaureix J, Le Minor S. Serratia marcescens, modèle d'infection hospitalière. [Serratia marcescens, a model for hospital infection]. Bull Acad Natl Med 1984; 168: 330335 .

4. Okuda T, Endo N, Osada Y, Zen-Yoji H. Outbreak of nosocomial urinary tract infections caused by Serratia marcescens. J Clin Microbiol 1984; 20: 691-695.

5. Wilhelmi I, Bernaldo de Quirós JCL, Romero-Vivas J, Duarte J, Rojo E, Bouza E. Epidemic outbreak of Serratia marcescens infection in a cardiac surgery unit. J Clin Microbiol 1987; 25: 1298-1300.

6. Krishnan PU, Pereira B, Macaden R. Epidemiological study of an outbreak of Serratia marcescens in a haemodialysis unit. $J$ Hosp Infect 1991; 18: 57-61.

7. Schaberg DR, Alford RH, Anderson R, Farmer JJ, Melly MA, Schaffner W. An outbreak of nosocomial infection due to multiply resistant Serratia marcescens: evidence of interhospital spread. $J$ Infect Dis 1976; 134: 181-188.

8. Knothe H, Shah P, Krcmery V, Antal M, Mitsuhashi S. Transferable resistance to cefotaxime, cefoxitin, cefamandole and cefuroxime in clinical isolates of Klebsiella pneumoniae and Serratia marcescens. Infection 1983; 11: 315-317.

9. Jarlier V, Nicolas MH, Fournier G, Philippon A. Extended broad-spectrum $\beta$-lactamases conferring transferable resistance to newer $\beta$-lactam agents in Enterobacteriaceae: hospital prevalence and susceptibility patterns. Rev Infect Dis 1988; 10: $867-878$.

10. Jacoby GA, Medeiros AA. More extended-spectrum $\beta$-lactamases. Antimicrob Agents Chemother 1991; 35: 1697-1704.

11. Sirot DL, Goldstein FW, Soussy CJ et al. Resistance to cefotaxime and seven other $\beta$-lactams in members of the family Enterobacteriaceae: a 3-year survey in France. Antimicrob Agents Chemother 1992; 36: 1677-1681.

12. Pitt TL, Erdman YJ, Bucher C. The epidemiological type identification of Serratia marcescens from outbreaks of infection in hospitals. $J$ Hyg 1980; 84: 269-283.

13. Pitt TL. State of the art: typing of Serratia marcescens. J Hosp Infect 1982; 3: 9-14.

14. Grimont F, Grimont PAD. The genus Serratia. In: Balows A, Trüper HG, Dworkin M, Harder M, Schleifer KH (eds) The procaryotes, New York, Springer-Verlag. 1991: 2822.

15. Goullet P. Characterization of Serratia marcescens, S. liquefaciens, $S$. plymuthica and $S$. marinorubra by the electrophoretic patterns of their esterases. J Gen Microbiol 1978; 108: 275281.

16. Grimont PAD, Grimont F. Proteinase zymograms of Serratia marcescens as an epidemiologic tool. Curr Microbiol 1978; 1: $15-18$.

17. Gargallo-Viola D, López D. Numerical analysis of electrophoretic periplasmic protein patterns, a possible marker system for epidemiological studies. J Clin Microbiol 1990; 28: 136139.

18. Picard B, Bruneau B, Goullet P. Demonstration of an outbreak of Serratia marcescens infections in a medical intensive care unit by esterase electrophoretic typing. $J$ Hosp Infect 1988; 11: 194-195.

19. Larose P. Picard B, Thibault F, Grimont F, Goulett P. Nosocomial Serratia marcescens individualized by five typing methods in a regional hospital. J Hosp Infect 1990; 15: 167 172.

20. Arzese A, Botta GA, Gesu GP, Schito P. Evaluation of a computer-assisted method of analysing SDS-PAGE protein profiles in tracing a hospital outbreak of Serratia marcescens. $J$ Infect 1988; 17: 35-42.

21. Holmes B, Costas M, Sloss LL. Numerical analysis of SDSPAGE protein patterns of Serratia marcescens: a comparison with other typing methods. Epidemiol Infect 1990; 105: 107117.

22. McGeer A, Low DE, Penner J, Ng J, Goldman C, Simor AE. Use of molecular typing to study the epidemiology of Serratia marcescens. J Clin Microbiol 1990; 28: 55-58.

23. Tompkins LS, Plorde JJ, Falkow S. Molecular analysis of Rfactors from multiresistant nosocomial isolates. $J$ Infec Dis 1980; 141: $625-636$.

24. Bullock DW, Bidwell JL, Reeves DS et al. Outbreaks of hospital infection in southwest England caused by gentamicinresistant. Serratia marcescens. J Hosp Infect 1982; 3: 263273.

25. John JF, Twitty JA. Plasmids as epidemiologic markers in nosocomial gram-negative bacilli: experience at a university and review of the literature. Rev Infect Dis 1986; 8: 693-704.

26. Mayer IW. Use of plasmid profiles in epidemiologic surveillance of disease outbreaks and in tracing the transmission of antibiotic resistance. Clin Microbiol Rev 1988; 1: 228-243.

27. Bingen $\mathrm{EH}$, Mariani-Kurkdjian $\mathrm{P}$, Lambert-Zechovsky $\mathrm{N}$ et al. Ribotyping provides efficient differentiation of nosocomial Serratia marcescens isolates in a pediatric hospital. $J$ Clin Microbiol 1992; 30: 2088-2091.

28. Alonso R, Aucken HM, Perez-Diaz JC, Cookson BD, Baquero F, Pitt TL. Comparison of serotype, biotype and bacteriocin type with rDNA RFLP patterns for the type identification of Serratia marcescens. Epidemiol Infect 1993; 111: 99-107.

29. Liu PY-F, Lau Y-J, Hu B-S et al. Use of PCR to study epidemiology of Serratia marcescens isolates in nosocomial infection. J Clin Microbiol 1994; 32: 1935-1938.

30. Llanes C, Couturier M, Asfeld L, Grimont F, Michel-Briand Y. Replicon typing of 71 multiresistant Serratia marcescens strains. Res Microbiol 1994; 145: 17-25.

31. Goullet P. Picard B. The electrophoretic polymorphism of bacterial esterases. FEMS Microbiol Rev 1995; 16: 7-31.

32. Acar J, Bergogne-Bérézin E, Brogard JM et al. Communiqué du Comité de l'Antibiogramme de la Société Française de Microbiologie. Pathol Biol 1993; 41: 741-748.

33. Philippon A, Fournier G, Paul G, Vedel G, Nevot P. Détection 
et distribution des bêta-lactamases à spectre élargi chez les entérobactéries. Med Mal Infect 1988; 12: 869-876.

34. Lennox ES. Transduction of linked genetic characters of the host by bacteriophage $P_{1}$. Virology $1955 ; 1$ : 190-206

35. Uriel J. Méthode d'électrophorèse dans des gels d'acrylamideagarose. [Method of electrophoresis in acrylamide-agarose gels]. Bull Soc Chim Biol 1966; 48: 969-982.

36. Goullet P, Picard B. A two-dimensional electrophoretic profile for bacterial esterases. Electrophoresis $1985 ; 6$ : 132-135.

37. Uriel J. Caracterisation d'enzymes par électrophorèse en gélose. In: Loiseleur J (ed) Technique de laboratoire. Paris, Masson. 1963.

38. Selander RK, Caugant DA, Ochman H, Musser JM, Gilmour MN, Whittam TS. Methods of multilocus enzyme electrophoresis for bacterial population genetics and systematics. Appl Environ Microbiol 1986; 51: 873-884.

39. Gargallo-Viola D. Enzyme polymorphism, prodigiosin production, and plasmid fingerprints in clinical and naturally occurring isolates of Serratia marcescens. J Clin Microbiol 1989; 27: $860-868$

40. Platt DJ, Sommerville JS. Serratia species isolated from patients in a general hospital. $J$ Hosp Infect 1981; 2: 341-348.
41. Le Minor S, Pigache F. Etude antigénique de souches de Serratia marcescens isolées en France. II. Caractérisation des antigènes $O$ et individualisation de 5 nouveaux facteurs, fréquence des sérotype et désignation des nouveaux facteurs H. [Antigenic study of 'Serratia marcescens' isolated in France. II. Characterization of $\mathrm{O}$ antigens and description of 5 new $\mathrm{O}$ factors, occurrence of serotypes and labelling of new $\mathrm{H}$ factors.] Ann Microbiol 1978; 129B: 407-423.

42. Rubin SJ, Brock S. Chamberland M, Lyons RW. Combined serotyping and biotyping of Serratia marcescens. $J$ Clin Microbiol 1976; 3: 582-585.

43. Franczek SP, Williams RP, Hull SI. A survey of potential virulence factors in clinical and environmental isolates of Serratia marcescens. J Med Microbiol 1986; 22: 151-156.

44. Marre R, Hacker J, Braun V. The cell-bound hemolysin of Serratia marcescens contributes to uropathogenicity. Microb Pathog 1989; 7: 153-156.

45. Traub WH. Virulence of nosocomial isolates of Serratia marcescens for NMRI mice: correlation with O-antigens O6 and O14. Zentralbl Bakteriol Mikrobiol Hyg A 1982; 252: 360-369. 